\title{
What future for gender equality policy in the UK after Brexit?
}

\author{
RACHEL VERDIN
}

University of Sussex

AND

JACQUELINE O'REILLY

University of Sussex

\begin{abstract}
The evolution of gender equality policies in the UK prior to, and since, entering the Common Market in the 1970s illustrates the distinctive characteristics of the UK employment system. This can be understood as a movement between bistorically embedded voluntarism and periods of statutory compliance. European influence on British policies has been filtered through the interests and interaction of four key sets of actors: governments, the legal system, employers and unions. An historical analysis of gender equality policies suggests that the potential future consequences of Brexit are likely to be patterns of continuity, change and unintended consequences. Continuity indicates that existing regulations will persist, until they are challenged. Change will see a removal of appeal to EU-level adjudication. Some unintended consequences may emerge related to the impact of migration patterns and the behaviour of large-scale companies working in the UK which could have unexpected positive outcomes. The analysis in this paper suggests that this will remain a contested terrain.
\end{abstract}

Key words: gender equality; Brexit; voluntarism; statutory compliance; EU.

\section{Introduction}

7 he development of UK employment equality law has had a positive yet hesitant and incomplete trajectory, according to Dickens. ${ }^{1}$ It has moved from legislation on antidiscrimination towards measures to encourage greater equality. This marks a transition from a piecemeal, pragmatic and patchwork coverage to more inclusive, integrated and intersectional approaches since the 1970s. Nevertheless, while this trajectory has strengths and efficacy, there are limitations in legal packages and enforcement mechanisms that continue to be contested in relation to implementation and litigation.

The role of the EU's gender equality framework, including both hard and soft law, through gender mainstreaming, has been very significant for UK policymaking. But Fagan and Rubery suggest that the development of this policy highlights persistent contradictions and political tensions between social democratic principles and neoliberal policies within the EU. ${ }^{2}$ In the UK these tensions are likely to be exacerbated by

1 Linda Dickens, 'The road is long: thirty years of equality legislation in Britain' (2007) 45 British Journal of Industrial Relations 463.

2 Collete Fagan and Jill Rubery, 'Advancing gender equality through European employment policy: the impact of the UK's EU membership and the risks of Brexit' (2018) 17 Social Policy and Society 297. 
decoupling from the EU's equality framework and pursuing a more insular position where key actors, based in the national jurisdiction, will dominate future developments.

According to Dickens, catalysts for greater equality in the UK have included both internal and external factors. ${ }^{3}$ Internal factors include various protests and political mobilisation, as well as riots since the 1970s and 1980s. These protests have influenced the take-up of anti-discrimination policy in UK around gender, race and disability. External factors include influences from the USA as well those from the EU. In the USA, Dobbin has argued that the equal opportunities and diversity agenda has largely been the creation of human resource professionals. ${ }^{4}$ In some cases, organisational practices from the USA provide examples of 'best practice'. ${ }^{5}$ In the EU, Fagan and Rubery 6 suggest that the early UK legislation on equal pay and sex discrimination was only introduced 'after being offered in membership and to coincide with the EU legislation'. Subsequent adoption of EU policies in the UK was often reluctantly, or only partially, implemented, for example, in relation to the Working Time Directive and gender mainstreaming.

However, this top-down, external effect perspective somewhat underplays the importance of local and national actors contesting discriminatory unequal practices, for example, in the early Dagenham dispute on equal pay and the recent 'no-win no-fee' cases in local government, as well as high-profile cases at the BBC and major retailers like ASDA. ${ }^{7}$ Many of these earlier, and more recent, challenges reflect a resistance to the established gender order ${ }^{8}$ or the conventional gender norms based on women's primary role as care-givers and their secondary status as workers. ${ }^{\text {? }}$

\section{From voluntarism to statutory compliance in the UK}

The UK has a long and distinctive legal tradition in relation to employment regulation based on liberal principles of 'freedom of contract'. In contrast to the practices on the European continent governed by the principles of 'positive liberty' and enshrined in the Code du Travail, as in France, British employers have largely been at liberty to offer employment contracts at will. In contrast, on the continent in legal systems that are more defined by positive liberty employers can only offer employment contracts specified in the codified labour law. This has constrained their ability to introduce flexibility in a comparable way to employers in the UK. ${ }^{10}$

Against the backdrop of this fundamental difference in the legal system governing employment contracts there has also been a tendency in the UK for voluntarist

3 Dickens (n 1).

4 Frank Dobbin, Inventing Equal Opportunity (Princeton Press 2009).

5 Indirectly the framing of the Fair Employment (Northern Ireland) Act 1989 was influenced by US practices around positive discrimination but was specifically not applied to the rest of the UK, as per Dickens (n 1) 466.

$6 \quad$ Fagan and Rubery (n 2) 301.

7 Simon Deakin, Sarah Fraser Butlin, Colm McLaughlin and Aleksandra Polanska, 'Are litigation and collective bargaining complements or substitutes for achieving gender equality? A study of the British Equal Pay Act' (2015) 39 Cambridge Journal of Economics 381.

8 Dickens (n 1).

9 Hazel Conly and Margaret Page, 'The good, the not so good and the ugly: gender equality, equal pay and austerity in English local government' (2018) 32 Work, Employment and Society 789; Fagan and Rubery (n 2); Nuria Sánchez-Mira and Jacqueline O'Reilly, 'Household employment and the crisis in Europe' (2019) 33(3) Work, Employment and Society 422-443 <https://doi.org/10.1177/0950017018809324>.

10 Jacqueline O'Reilly, Banking on Flexibility: Comparing Flexible Employment Practices in Retail Banking in Britain and France (Avebury 1994). 
arrangements between employers and trade unions. In part this derives from the $1970 \mathrm{~s}$ when trade unions were considerably stronger in demanding the right to free collective bargaining. As with some major industrial unions on the European continent, the ability for unions to negotiate terms and conditions of work was considered more beneficial than relying on minimal statutory implementation, as was the case in France where unions were considerably weaker. So, in countries like Germany, where there was a strong tradition of industry-wide collective bargaining, unions were quite resistant to the imposition of statutory regulation.

However, the deteriorating conditions of employment and the subsequent diminishing of the status of trade unions in the UK modified opinions about the values of state interventions and legal judgments. This happened much earlier in the UK than in other parts of Europe, as evidenced, for example, with the introduction of the National Minimum Wage (1998). The move away from voluntarism in the UK started to become evident in the 1980s with the advent of the Conservative government and the decimation of the trade unions. UK unions, which in some cases may have been quite hostile to the EU (at that time the Common Market), subsequently drew on legal decisions from the European Court of Justice (ECJ) to enforce workers' rights in the UK. ${ }^{11}$

Alongside this deep-running tendency for voluntarism in the UK there coexisted a strong strand of voluntarism in the business community supported by both Conservative and New Labour governments. Essentially, this disposition implied that businesses were best suited to organising their own affairs, rather than relying on government intervention in the form of employment regulation. One of the key characteristics of the UK system of employment relations has been this deeply embedded strand of voluntarism.

Despite these inclinations for governments to provide a 'light touch' to the regulation of employment relations, there has been an increasing level of enforcing statutory compliance, as exemplified in the most recent statutory implementation of Gender Pay Audits. To understand these changes, we trace back the role of the four core actors in the historical development of equality policies in the UK and EU.

\section{European influences on gender equality policies in the UK}

The EU approach to equality has been central to the UK's legislative development since the outset. As per Article 119 in the Treaty of Rome 1957, the new and developing EU had stated:

Each Member State shall ... ensure and subsequently maintain the application of the principle that men and women should receive equal pay for equal work. ${ }^{12}$

The inclusion of equal pay was largely due to French concerns over other member states gaining a competitive advantage, particularly as the minimum wage in France applied to both men and women, whereas in the Netherlands it only applied to men. France had already enacted its own equal pay provisions and feared that cheap labour, in particular in the garment industry, would put the country at a competitive disadvantage. ${ }^{13}$

11 Abigail Gregory and Jacqueline O’Reilly, 'Checking out and cashing up: the prospects and paradoxes of regulating part-time work in Europe' in Rosemary Crompton, Duncan Gallie and Kate Purcell, Changing forms of Employment: Organisations, Skills and Gender (Routledge 1996) 207-234.

12 Article 157 of the Treaty on the Functioning of the European Union (originally Article 119 of the Treaty of Rome Establishing the European Community 1957).

13 Susanne Burrie and Sacha Prechal, 'EU gender equality law' (European Commission Report, Brussels 2013) $1,2$. 
The economic perspective on equal pay has remained at the forefront throughout its legislative development. ${ }^{14}$ However, the ECJ clarified in Defrenne $v$ Sabena that the rationale for equal pay should also include a social aim:

The provision forms part of the social objectives of the Community, which is not merely an economic union, but is at the same time intended, by common action, to ensure social progress and seek the constant improvement of the living and working conditions ... This double aim, which is at once economic and social, shows that the principle of equal pay forms part of the foundations of the Community. ${ }^{15}$

Correspondingly, the UK's decision to join the EU had important ramifications for its own approach. This was accompanied by a political climate that was increasingly favourable to recognition of the profound changes to women's role in society and the economic structure of the home. ${ }^{16}$ Alongside this, industrial action and campaigning, particularly by the Ford sewing machinists at Dagenham, the Women's Liberation Movement and National Joint Action Campaign Committee for Women's Equal Rights, the backdrop within the UK for the implementation of the Equal Pay Act 1970 (EqPA70) was set.

The economic tension and resistance from business brought about by the passing of EqPA70 is notable in the timeframe given for its implementation and in the wording of the legislation itself. ${ }^{17}$ The Act required equal pay for work that was the same, similar or broadly equivalent. While broadly equivalent went further than the provision in the Treaty of Rome, equal value was not considered an appropriate inclusion. ${ }^{18}$ However, the EU developed the provision and recognised the importance of equal value 10 months prior to the enactment of the EqPA70 within the UK. ${ }^{19}$ While the legislative process takes time, the political will for further change in the UK was clearly not apparent and tempered by the explicit lack of business motivation for any expansion of the legislation. Ultimately, the UK's failure to comply in this regard resulted in proceedings from the EU and in 1983 the Equal Value Amendment (EVA83) was passed. This demonstrates the conflicting elements of ongoing campaigning and movement to support social progress

14 Dickens (n 1); Linda Hantrais, 'Assessing the past and future development of EU and UK social policy' (2018) 17 Social Policy and Society 265; Ania Plomien, 'EU social and gender policy beyond Brexit: towards the European Pillar of social rights' (2018) 17 Social Policy and Society 281.

15 Defrenne $v$ Sabena [1976] ECR 455 (ECJ) Case 43/75, paras 122-123.

16 Office for National Statistics, 'Women in the labour market: 2013' (ONS 2013)

$<$ https://www.ons.gov.uk/employmentandlabourmarket/peopleinwork/employmentandemployeetypes/arti cles/womeninthelabourmarket/2013-09-25>. In 1964 the Labour Party election manifesto made a commitment to equal pay in its proposed 'Charter of Rights': 'Manifesto: the New Britain' (Labour Party 1964) <www.labour-party.org.uk/manifestos/1964/1964-labour-manifesto.shtml>; and again in 1966, 'Manifesto: you know Labour government works: time for decision' (Labour Party 1966) <wwwlabourparty.org.uk/manifestos/1966/1966-labour-manifesto.shtml>.

17 The CBI lobbied for a seven-year period of salary adjustment, while the Trades Union Congress opted for two years (HC Deb 9 February 1970, vol 795, col 923W); also discussed in Laura Levine Frader, 'International institutions and domestic reform: equal pay and British membership in the European Economic Community' (2018) 29 Twentieth Century British History 104, 118.

18 Barbara Castle, in introducing the legislation to the Commons, stated that 'The phrase "equal pay for work of equal value" is too abstract a concept to embody in legislation', with which the CBI agreed (HC Deb 9 February 1970, vol 795, col 916W).

19 The Equal Value Amendment was raised in the Official Journal in February 1974 (OJ No C 13, 12.2.1974). By February 1975 a Directive outlining the principle had been agreed (Council Directive (EEC) 75/117 on the approximation of the laws of the Member States relating to the application of the principle of equal pay for men and women [1975] OJ L 045 19/2/1975 0019-0020). 
alongside a government happy to defer to a more cautious voluntarist business-led approach to addressing the gender pay gap in the UK.

Similar patterns of resistance to change and partial application of European Directives can be seen in the subsequent development of UK law directed at gender pay inequality. ${ }^{20}$ For instance, the partial implementation of the European Directive required enactment of the Part-time Workers Regulations 2000 (PTWR00) in UK statute. ${ }^{21}$ The UK chose not to legislate around the clause 5 requirements which were aimed at making wider improvements to flexibility in the labour market and helping the reconciliation of work and family life, opting instead for best-practice guidance in that regard. ${ }^{22}$ While the impact of the EU is clear from the outset of the UK's relationship, a political will, the needs of business and the wider social climate have also provided both stimuli and resistance to development of the UK's equality provisions in a sustained way since. ${ }^{23}$

Discussion of the period surrounding the Equality Act 2010 (EqA2010), which this article positions as the current legal context, highlights the current framework of competing factors in the law's interaction with social actors. ${ }^{24}$ European influence has been filtered through the four key actors shaping gender equality policies in the UK: governments, the legal system, employers and unions. There has been an inherent and deep-running tension between seeking to address social policy goals and neoliberal politics. ${ }^{25}$ They will be discussed in light of how they have shifted the debate forwards, or alternatively obstructed progress to achieving gender pay parity.

\section{Equality initiatives contextualised by the 2008 financial crisis setbacks}

The financial crisis of 2008 was the most significant economic shock since the depression of the 1930s. ${ }^{26}$ It prompted an unprecedented response in terms of the financial bailout and resulted in a deep recession, both within the UK and across the rest of Europe. Politically, the repercussions were equally catastrophic. ${ }^{27}$ The Labour Party's stewardship through the financial crisis ultimately eroded the electorate's faith in its capacity or competence to rebuild the economy, despite Gordon Brown's image as the 'Iron Chancellor'. ${ }^{28}$ While there were numerous other factors at play, resulting in the Labour government's failure in the 2010 election, the party's programme of spending, unwillingness to adopt an activist response to the crisis, blame attributed to the lack of financial regulation, and its light-touch approach during its period in office, undoubtedly

20 Fagan and Rubery (n 2); Hantrais (n 14); Plomien (n 14).

21 Council Directive (EC) 97/81 of 15 December 1997 concerning the Framework Agreement on part-time work [1998] OJ L 14, 20/01/1998, 9-14.

22 Mark Bell, 'Achieving the objectives of the Part-Time Work Directive? Revisiting the Part-Time Workers Regulations' (2011) 3 Industrial Law Journal 254, 255.

23 Dickens (n 1); Frader (n 17).

24 Margaret Davies, 'Feminism and the flat law theory' (2008) 16 Feminist Legal Studies 281.

25 Dickens (n 1); Deakin et al (n 7); Jill Rubery and Damian Grimshaw, 'The 40 year pursuit of equal pay: a case of constantly moving goalposts' (2015) 39 Cambridge Journal of Economics 319.

26 Jacqueline O'Reilly, David Lain, Maura Sheehan, Bob Smale and Mark Stuart, 'Managing uncertainty: the crisis, its consequences and the global workforce' (2011) 25(4) Work, Employment and Society 581-95; Harold Clarke, David Sanders, Marianne Stewart and Paul Whiteley, 'Valence politics and the electoral choice in Britain, 2010' (2011) 21 Journal of Elections, Public Opinion and Parties 237; Peter Taylor-Gooby, The Double Crisis of the Welfare State and What We Can Do about It (Palgrave Macmillan 2013) 3.

27 O'Reilly et al (n 26).

28 Clarke et al (n 26). 
contributed to the result. ${ }^{29}$ The vulnerable and uncertain economic climate witnessed shifting political sands as the Labour government was replaced by a Conservative/Liberal Democrat Coalition in 2010. This result, and the approach subsequently pursued to address the financial crisis, impacted equality measures in several ways, both within the scope of the EqA2010 and beyond.

The political choice of austerity as a means to address the government deficit has seen state spending cuts at unprecedented levels. ${ }^{30}$ The programme of cuts introduced resulted in a significant reduction in state services, alongside associated cuts in benefit provision, resulting in an overall reduction in state support. ${ }^{31}$ These measures were accompanied by a public-sector pay freeze between 2010 and 2012, followed by a 1 per cent pay cap, below the level of inflation.

To further disadvantage the largely female workforce, public sectors, such as the care sector, were outsourced and so were subsequently beyond the scope of local authority job evaluation and single-status pay scales. ${ }^{32}$ Despite the adoption of gender mainstreaming, and commitment to pay 'due regard' to the need to advance equality of opportunity in the EqA2010, as per the public sector equality duty requirements, changes were implemented without any reference to the inequality of impact they might have. It has since been widely noted that this package of measures has led to increasing inequalities, felt most by women and those with 'intersecting disadvantages'.33

This contextual analysis demonstrates that the growing preference for reflexive legislation is at odds with the UK's focus on addressing the government deficit and the narrative of cutbacks and efficiencies pursued. Despite the binding effect of Treaty obligations on the UK, austerity served to deprioritise equality and shift the focus of government. ${ }^{34}$ Notably there were no equality impact assessments (EIAs) carried out on the programme of government cuts. 35

This shift in gender relations is again notable by the subsequent abolition of EIAs, part of David Cameron's announcement to the 2011 Confederation of British Industry (CBI) conference, with the intention to reduce unnecessary and costly government

29 Ben Jackson, 'Learning from New Labour' (2018) 89 Political Quarterly 3; Patrick Diamond, 'The progressive dilemmas of British social democracy: political economy after New Labour' (2013) 15 British Journal of Politics and International Relations 89, 95.

30 Taylor-Gooby (n 26).

31 Catherine Albertyn, Sandra Fredman and Judy Fudge, 'Introduction: elusive equalities - sex, gender and women' (2014) 10 International Journal of Law in Context 421; Julie MacLeavy, 'Women, equality and the UK's EU referendum: locating the gender politics of Brexit in relation to the neoliberalising state' [2018] Space and Polity 1.

32 Conly and Page (n 9) 800-01.

33 Sue Durbin, Margaret Page and Sylvia Walby, 'Gender equality and "austerity": vulnerabilities, resistance and change’ (2017) 24 Gender, Work and Organisation 1; Taylor-Gooby (n 26) 12; Jill Rubery, 'Austerity and the future for gender equality in Europe' (2015) 68 ILR Review 715.

34 A new emphasis to addressing inequality can be seen in the EU's adoption of gender mainstreaming as a new strategy in 1996, alongside an increased focus on the equality agenda, as per Teresa Rees, 'Reflections on the uneven development of gender mainstreaming in Europe' (2005) 7 International Feminist Journal of Politics 555. This was given binding effect in member states by the Treaty of Amsterdam (Treaty of Amsterdam Amending the Treaty on European Union [1997] OJ C 340, 10/11/97 1-144) that came into force in 1999. Key provisions were included in Article 2 and Article 3(2), which required: 'In all [its] activities ... the Community shall aim to eliminate inequalities, and to promote equality, between men and women.'

35 Conley and Page (n 9). 
bureaucracy. ${ }^{36}$ This was part of a series of measures, known as the 'Red Tape Challenge', introduced in April 2011. This illustrates the long-running relationship between government and employers in the UK and the preference for a neoliberal agenda to 'reduce the burden on business'.

The specific impact of the political climate, the needs of the economy and a wider social context will now be outlined with reference to the EqA2010, and how it is applied. Just as these themes were pertinent in the early development of equality provision, they remain just as relevant now. As such, they are used here to help assess the prospects for our current legislative landscape beyond Brexit.

\section{The Equality Act 2010: a consolidation or radical reform?}

The introduction of the EqA2010 indicated a watershed in the UK's approach to equality. The disparate nature of exiting provisions, alongside their respective shortcomings, required updating. Legislative efforts to approach inequality have changed. The purely prohibitive requirements of the EqPA70 and Sex Discrimination Act 1975 were extended and developed by the EVA83. Developments since have seen the implementation of varied provisions impacting on the causes of gender pay inequality rooted in both European regulation and UK-based initiatives. ${ }^{37}$ This resulted in the UK's equality laws being spread over 116 separate legislative provisions, prior to the enactment of the EqA2010. These had grown and developed in a piecemeal way, reflected by the inconsistency and complex nature of their approaches.

The Act's journey to the statute book marked an extended period of review and consultation prior to that point. ${ }^{38}$ As one of the final legislative acts of the outgoing government, the EqA2010 highlights how the Labour Party was demonstrably embracing the need for good governance, alongside a political commitment to enhance equality provisions. ${ }^{39}$ The Act included proposals to acknowledge the importance of, and attempt to tackle, socio-economic inequality, to use the public sector to model good behaviour and promote equality, and go beyond legislation prohibiting unequal pay to a requirement to publish gender pay gaps. ${ }^{40}$

These represent key developments that were not all based in EU requirements but reflected commitments arising from the political will and social climate of the time in the

36 Doug Pyper, 'The public sector equality duty and equality impact assessments' (Briefing Paper 06591, House of Commons Library 2018)

<https://researchbriefings.files.parliament.uk/documents/SN06591/SN06591.pdf>.

37 For instance, improved maternity entitlements and the right to request flexible working alongside more proactive requirements, such as gender and race equality duties.

38 The case for updating and improving existing equality law was well made by the independent assessment of existing equality legislation in the Cambridge Review in 2000. The National Equality Panel, set up in 2008, outlined the proposals for an Equality Bill to reflect the changing nature and understanding of equality in society: The Equality Bill - Government Response to the Consultation (GEO 2008)

$<$ https://www.gov.uk/government/publications/the-equality-bill-government-response-to-theconsultation>; Bob Hepple, Equality: A New Framework: Report of the Independent Review of the Enforcement of UK Anti-discrimination Legislation (Hart 2000).

39 New Labour's concern with bringing the government closer to the people echoed the EU desire for a more accountable inclusive EU as per Byron Sheldrick, 'New Labour and the third way: democracy, accountability and social democratic politics' [2002] Studies in Political Economy 133.

40 EqA2010: section 1, 'Socio-economic duty'; section 149, 'Public sector equality duty'; and section 78, 'Gender pay reporting'. 
UK. ${ }^{41}$ The new Equality Bill, as was, was first announced in December 2008 and was finally enacted in October 2010. ${ }^{42}$ The EqA2010, in compliance with the EU's better legislation programme, intended to make the various equality strands more readable, accessible and transparent. The Act harmonised and reformed the law in potentially decisive ways for gender pay inequality, formalising a shift in approach and attempting to consistently recognise the need for more affirmative action as a means to tackle inequality, as opposed to a purely reactive approach. ${ }^{43}$

Through updating, consolidating and providing some consistency to existing provisions, the EqA2010 also introduced a mandate for new requirements. For instance, Part 11, 'Advancement of equality', acknowledged that equality law is not just about treating everyone the same, but taking additional steps to level existing inequality. Significantly, it introduced proactive measures that attempted to reposition the claimantcentred approach to equality law, which has limited its applicability in the UK, by specifically acknowledging the need to take positive action to address historical disadvantages and, in so doing, has been described as potentially 'transformative'. ${ }^{44}$

\section{Measures to improve pay transparency}

The requirement for gender pay reporting represented a significant step in requiring employers to recognise their own gender pay inequality and, in so doing, hopefully prompt organisational efforts to address the findings, not dependent on the individual. This went beyond the scope of previous equal pay legislation. Section 78 required an annual publication of any difference in pay between men and women, potentially highlighting not only unequal pay but any organisational occupational segregation and the differential this produces, alongside inevitable pressure to improve year on year. This demonstrated a real commitment to the growing understanding of the factors that impact upon gender pay inequality.

This requirement represented a breakthrough in terms of pay inequality and was included alongside some other important changes, most notably around transparency in pay. Pay secrecy clauses while not prohibited - the clauses themselves are still legitimate - were rendered unenforceable by the Act when an employee is seeking a 'relevant pay disclosure' (section 77(1), EqA2010).

The introduction of statutory discrimination questionnaires enabled employees to ask questions in order to find out whether pay differences were discriminatory. This made pay structures potentially more transparent and the process of challenging inequities more accessible (section 138, EqA2010).

41 The UK acknowledgment of institutional racism, following the Stephen Lawrence enquiry and Macpherson Report in 1999 (Sir William Macpherson, Report of the Stephen Lawrence Inquiry (Home Office, Cm 4262-I, 1999), prompted the creation of the race equality duty. This was introduced as an attempt to challenge historical and cultural disadvantage and change attitudes towards discrimination both within organisations and the services they provide (April 2001, inserting section 71 as amendment to Race Relations Act 1975). The gender and disability duties followed in its wake (2007). This represented a new understanding of how inequality pervades society and social structures and introduced a more proactive approach as a means to tackle systemic organisational failures. The EqA2010 introduced the new single equality duty, harmonising and extending the race, disability and gender equality duties.

42 GEO, The Equality Bill (GEO 2008) <https://d3n8a8pro7vhmx.cloudfront.net/labourclp63/pages/1284/attachments/original/1414676999/ Equalities_ACt_fact_sheet.pdf?1414676999>.

43 Colm McLaughlin and Simon Deakin, 'Equality law and the limits of the "business case" for addressing gender inequalities’ (Working Paper 420, Centre for Business Research, University of Cambridge 2011).

44 Hepple (n 38). 
Tribunals were also given powers to make recommendations to benefit the wider workforce (section 124, EqA2010). This wider power enabled tribunals to not only make a ruling in favour of the claimant but extended the scope enabling rulings relating to the employer's whole workforce. For instance, in Tantum v Travers Smith Braithwaite Service, ${ }^{45}$ the tribunal recommended that the company be required to implement diversity training for all its staff. This element of collectivism in the outcome was previously missing from the law and again represented a development away from the wholly claimant-centred reach held by the law. It also illustrated the relationship between statutory obligation and legal enforcement through the judicial system.

\section{The 'Think, Act, Report' initiative 2011 - from voluntary to statutory pay audits}

The gender pay reporting requirements of the EqA2010 were not initially enacted, merely included, while voluntary measures were pursued in the first instance. ${ }^{46}$ The 'Think, Act, Report' 2011 initiative required companies to think about gender equality issues in the workplace, take action to address and improve them, and report on progress. ${ }^{47}$ 'Think, Act, Report' encouraged companies to publish their own pay data. With the intention of avoiding more stringent measures, the initiative highlighted the potential benefits of retaining and developing quality staff, the reputational effect of increased gender awareness and the opportunity publication and transparency would afford to promote good work.

However, after three years only five companies had reported on their pay gaps. ${ }^{48}$ As such the section $78 \mathrm{EqA} 2010$ requirement was brought into force requiring employers with over 250 employees to report and publish on various measurements of gender pay difference with regards to pay, bonus and breakdown of the division of staff within pay quartiles. This is now a legislative requirement (Equality Act (Gender Pay Reporting) Regulations 2017), with the Equality and Human Rights Commission setting out compliance procedures since March 2018. ${ }^{49}$ There are, however, no specific penalties for non-compliance, and the accompanying narrative outlining how the employer has or is addressing the problem is not specifically required.

Despite the potential for low-level compliance, given the intial lack of clarity in enforcement measures, teething problems associated with its introduction, and uncertainty around how many employers are covered by the regulations, the first year achieved 100 per cent compliance within four months of the deadline. ${ }^{50}$ This highlights a notable success for the EqA2010. In addition, the discussions and consultation it is now prompting, for instance, with reference to the publication of ethnicity and disability pay

45 Tantum v Travers Smith Braithwaite Service 2013 WL 10924087 (ET).

46 'Think, Act, Report' was a voluntary system devised by government in 2011 to encourage employers to publicly report on gender and equality issues.

47 The pay reporting provision was not initially enacted, with the Coalition government preferring this voluntary approach. Interestingly, the government is now consulting over ethnicity pay reporting. The Race Charter is hoping to emulate the success of the pay reporting regulations adopting a voluntary approach to reporting ethnicity pay gaps.

48 Patrick Wintour, 'Lib Dems push through mandatory reporting of gender pay gaps' The Guardian (London, 6 March 2015) <www.theguardian.com/money/2015/mar/06/lib-dems-push-mandatory-reporting-ofgender-pay-gaps $>$.

49 Equality and Human Rights Commission, 'Closing the gap: enforcing the gender pay gap regulations' (Equality and Human Rights Commission 2018) <www.equalityhumanrights.com/en>.

50 GEO, ‘100\% of UK employers publish gender pay gap data' (GEO Press Release 2018) <www.gov.uk/government/news/100-of-uk-employers-publish-gender-pay-gap-data>. 
gaps, highlights the potential benefits and transformative nature of the wholesale approach to equality that is afforded by the EqA2010.

\section{Assessment of the Equality Act 2010}

Assessment of the application of the EqA2010's provisions demonstrates the way that contextual factors have also stymied efforts at change. Disappointingly, powers for wider recommendations have been removed, meaning that employers can now choose if and how to approach any liability found in relation to their wider workforce, removing the much-needed element of collectivism. The questionnaire procedure has been repealed and the costs and bureaucracy of the socio-economic duty were also considered surplus to requirements and so never enacted. The commonalities in the impact of business needs, economic tension and political will frustrating the development of the law here also reiterate the difficulty of enabling change to move beyond the individual claimantcentred potential the law offers. Again, the incomplete implementation of the PTWR00 is illustrative of this trend and the divergent way that these factors can impact. Despite the government's original intention to provide best practice guidance regarding the Directive's clause 5 requirements of reforming flexibility in the labour market, this was subsequently not pursued. This underlines the earlier reluctance to effect the wider proposed remit of the legislation and is in stark contrast to the pay and gender differential between part-time and full-time roles. ${ }^{51}$ However, the more favourable political climate of the time is notable in the inclusion, beyond European requirements, of a written statement from employers, should less favourable treatment occur, and the extension of the provisions to agency and casual workers. Reference made in Parliament at the passing of the Bill, from the other side of the House, to the government gold-plating the already burdensome and costly nature of the regulations highlights these political and economic tensions. ${ }^{52}$ This positions the development and progress of equality law within the UK as very much beholden to factors outside the scope of the EU, as well as alongside it.

The development of legal provision within the EqA2010 shows a partial shift towards a more proactive role for the law, given the implementation of statutory compliance with gender pay audits. This shift correspondingly echoes the ongoing reluctance to proscribe and enforce change in deference of business needs. A key feature of the current legislative climate remains its continued, albeit altered, pursuance of discretionary measures. The pay reporting regulations are limited to employers with 250 or more employees and, as discussed, do not require the accompanying narrative addressing the reason for the pay gap. As such, any organisational efforts to address the problem do not need to be included or, indeed, even attempted. While the commitment to voluntarism could be predicted to be unsuccessful, given the historic lack of voluntary change, it reflects on the deeply embedded characteristic of the UK system of employment relations and government-business relations.

The public visibility associated with the international social movement stemming from \#timesup and \#metoo has re-awakened public awareness of demands for gender equality. The social media campaigns have achieved influence and a new-found willingness for a public narrative about the experience of harassment and abuse for women. In turn, the timing of these social movements coincided with the implementation of the gender pay reporting regulations in the UK and undoubtedly helped redouble their impact. This can be seen by the furore surrounding the BBC's gender pay inequality and in its subsequent

51 Median hourly earnings for part-time workers at the time the legislation was passed was 59 per cent of their full-time counterparts, with women comprising 80 per cent of those roles, as per Bell (n 22) 268-269.

52 HL Debs 22 May 2000, vol 613, cols WA557-64. 
self-implemented target of a zero per cent pay gap by $2020 .{ }^{53}$ The potency of the movement has underlined the importance of collectivism, particularly in a climate of reduced collective bargaining. ${ }^{54}$ However, a public forum for debate around victims of inequality is not a panacea and does not, of itself, signal meaningful change. What it has done is starkly highlight the multitude of ways that inequality pervades society and social interaction and, in so doing, reiterated the importance of transparency and collectivism around the problem.

\section{Retrenchment: unfair dismissal rights and conditional fee arrangements}

The use of litigation and the legal system has been and remains a pertinent force and key actor in the UK's approach to equal pay. Its effectiveness can be seen in the wave of nowin no-fee equal value cases in the mid to late 2000s, which followed on from the large re-grading agreements in the public sector. ${ }^{55}$ These cases illustrate how statutory measures have been taken up through the legal system and resulted in some very significant financial settlements. ${ }^{56}$

This tide of no-win no-fee cases was partially blocked from May 2014 as associated employment law reforms were progressed, including: extending the qualifying period for unfair dismissal rights from one to two years; $; 7$ and the introduction of tribunal fees, ${ }^{58}$ together with mandatory early conciliation. ${ }^{59}$ These changes occurred alongside changing conditional fee arrangements and the reduction of legal aid and, as such, present a myriad of obstacles to anyone wishing to challenge gender pay inequities. These measures were again intended to reduce the burden on tribunals, give employers greater freedoms and reduce the costs on government budgets.

Assessing the impact of this subsequent legislation highlights how the potential to redress inequality through litigation is limited by its claimant-centred approach and the question of access to justice. These changes compounded the difficulties already discussed, such as the lack of collectivism in pursuance of equal pay, given the declining remit of collective bargaining and trade union membership, and the prior removal of the Central Arbitration Committee's ability to adjudicate in collective matters. ${ }^{60}$

This illustrates how both the economic crises and the political approach pursued in the aftermath led to a shift in the way individuals are able to use and apply the law. ${ }^{61}$ Gender equality was not a key priority in this time of crisis. Just as policy development in the UK and Europe was brought to a 'quasi-halt', after the financial crash the reach of

53 Graham Ruddick, 'Trust is broken at BBC over equal pay, Carrie Gracie tells MPs' The Guardian (London, 31 January 2018) <www.theguardian.com/media/2018/jan/31/bbc-in-real-trouble-over-equal-pay-carriegracie-tells-mps $>$. It is worth noting the furore was also fuelled by other areas of the media market.

54 Deakin (n 7).

55 Local Government Single Status Agreement in 1998 and, in the NHS, Agenda for Change 2004.

56 Barker v Birmingham City Council [2010] UKEAT 0056_10_0905.

57 As per the Unfair Dismissal and Statement of Reasons for Dismissal (Variation of Qualifying Period) Order 2012.

58 Employment Appeal Tribunal Fees Order 2013 (SI 2013/1893) was introduced in July 2013. This required claimants to pay fees to bring a claim to an employment tribunal. It was intended to assist in the planned reduction of the Ministry of Justice budget, as per Doug Pyper, Feargal McGuinness and Jennifer Brown, 'Employment tribunal fees' (Briefing Paper 7081, House of Commons Library 2017)

<http://researchbriefings.files.parliament.uk/documents/SN07081/SN07081.pdf>.

59 Under the Employment Tribunals (Early Conciliation: Exemptions and Rules of Procedure) Regulations 2014.

60 Deakin (n 7); Dickens (n 1).

61 Albertyn et al (n 31) 423. 
the law and an individual's ability to use it were equally undergoing challenging change. ${ }^{62}$ That said, litigants are still pursuing equal pay through the legal system as evidenced by the recent Glasgow case. ${ }^{63}$ The potential mooted liabilities for the pending equal value cases for $\mathrm{Asda}^{64}$ and Tesco demonstrate that the potency of this mechanism is not to be underestimated, despite these limiting factors. ${ }^{65}$

The EqA2010 and associated measures discussed here therefore represent a mixed picture of ideals impacted by the varied influence of the four key actors. While still embedded in a predominantly voluntarist tradition, we have seen a more proactive move to effective statutory compliance with driving mechanisms both internally and externally. The current gender pay reporting requirements may not result in more compulsory measures to address the cause of these inequalities after our withdrawal from the EU, but organisational approaches and the use of the legal system may still achieve traction on gender pay inequality.

\section{Post-Brexit scenarios}

Consideration now turns to how these key actors will continue to shape the UK's focus on gender equality measures post Brexit. European influence has been filtered through the four key actors shaping gender equality policies in the UK: governments, the legal system, employers and unions. First, the governmental approach and the future direction on equality measures is concerning. While it is early in a new Parliament, the removal from the European Union (Withdrawal Agreement) Bill 2019-2020 of clauses protecting workers' EU-derived rights has been accompanied by threats to curb trade unions' right to strike. ${ }^{66}$ The government proposed new legislation in the December 2019 Queen's Speech to ensure that employment protections are not eroded in the face of European measures, in the form of a forthcoming Employment Bill, but this has yet to come to fruition. The economic impact of exiting the EU is stark as forecasts both in terms of costs and future economic growth remain bleak. ${ }^{67}$ Equally, the diversion of resources that has already occupied significant parliamentary time is set to continue. ${ }^{68}$ Given the deprioritisation of equality measures that occurred in the aftermath of the financial crisis and the climate of austerity that followed, we can expect a further shift of resources to meet these alternative needs.

In addition, the parliamentary process and legislative development, as outlined here, is both slow-moving and incremental. It is therefore likely that any shift in approach towards targeted equality measures will be equally slow-moving. This will be combined with a disconnect, moving forward, from future policy development and change driven by

62 Annick Masselot, 'The EU childcare strategy in times of austerity' (2015) 37 Journal of Social Welfare and Family Law 345, 350.

63 HBJ Claimants v Glasgow City Council [2017] CSIH 56.

64 Asda Stores Ltd v Brierley [2016] EWCA Civ 566.

65 Sarah Butler, 'Tesco faces $f^{4}$ bn equal pay bill as claimant numbers swell to 1,000' The Guardian (London, 11 July 2018) <www.theguardian.com/business/2018/jul/11/tesco-faces-4bn-equal-pay-bill-as-claimantnumbers-swell-to-1000>.

66 Conservative Party 'Manifesto: get Brexit done: unleash Britain's potential' (Conservative Party 2019) $<$ https://vote.conservatives.com/our-plan>.

67 CBI, 'Brexit and the economic impact - where are we now? Implications for the UK economy since the vote to leave' The Business View (CBI 2019); Benjamin Nabarro and Christian Schulz, 'UK economic outlook in four Brexit scenarios' in The IFS Green Budget: October 2019 (Institute for Fiscal Studies 2019).

68 Kitty Stewart, Kerris Cooper and Isabel Shutes, "What does Brexit mean for social policy in the UK? An exploration of the potential consequences of the 2016 referendum for public services, inequalities and social rights' (Research Paper 3, Social Policy and Distributional Outcomes Programme 2019) 1, 19. 
the EU, resulting in lack of exposure to benchmarking and peer review, as suggested by the Open Method of Coordination. ${ }^{69}$ There may be a corresponding increase in the EU's regulatory approach, as the UK will no longer constrain progress, causing gaps to widen. ${ }^{70}$

There may be further unintended consequences on gender equality through the development of the UK's new approaches to policy, such as trade and migration. For instance, the ending of free movement will impact on the UK's labour market. Existing labour shortages in sectors such as care will be enhanced. ${ }^{71}$ Given the additional pressures of an ageing population and predictions surrounding technological innovations in the world of work, these pressures will be enhanced. ${ }^{72}$ This may mean increases in wages at the bottom of the pay spectrum, a projection seemingly supported by the 6.2 per cent increase in the Living Wage due to be implemented in April 2020. In addition, the expectation of jobs lost from the top of the earnings distribution, with predictions of 7000 finance jobs to be relocated, may see overall inequality decline. ${ }^{73}$

So, while there is no expectation of proactive development of new approaches to inequality, the impact of combined economic pressures may inadvertently create a more positive environment. That said, there is further caution to be noted from the developments and pressures that the fourth industrial revolution present as to how we will work in the future. As work relationships evolve, existing rights and protections may be eroded. ${ }^{74}$

The trajectory of the UK's equality policy will also continue to be impacted by the role of litigants and the courts. The prominence of gender pay inequality and media attention on the matter looks set to continue regardless of Brexit. High-profile equal pay cases, generating media attention in organisations such as the BBC, Co-op and ASDA, show no signs of slowing and demonstrate the potency that this element still holds. ${ }^{75}$ This is likely to remain impactful and set to continue, regardless of the UK's relationship with the EU.

\section{Conclusion: potential intended and unintended consequences}

The necessity of understanding how key actors have shaped equality policies in the UK suggests how future policies may develop. Here, we have first emphasised the role of government in its capacity to introduce legislative change and statutory compliance. Second, we turned to the role of the legal profession interpreting legislation in a number of high-profile cases. Third, we have focused on the role of employers and business organisations in the way these policies are implemented in a voluntaristic manner, with more recent evidence of statutory compliance. And, fourth, we have drawn attention to the long tradition of activists, litigants and, more recently, social media in maintaining a

69 Fiona Beveridge and Samantha Velluti, Gender and the Open Method of Coordination: Perspectives on Law, Governance and Equality in the EU (Ashgate 2008).

70 Fagan and Rubery (n 2).

71 Global Future, '100,000 carers missing: how ending free movement could spell disaster for elderly and disabled people' (Global Future Report 2018) <https://ourglobalfuture.com/reports/100000-carersmissing $/>$.

72 Alina Sorgner, Eckhardt Bode and Christiane Krieger-Boden, 'The effects of digitalization on gender equality in the G20 economies' (Women 20 Dialogue 2017) <www.w20germany.org/fileadmin/user_upload/documents/20170714-w20-studie-web.pdf>.

73 Danny Dorling, 'The curve of inequality and the Brexit way' (Brexit Blog, LSE 2019); Stewart et al (n 68 ) 35.

74 As demonstrated by the Taylor Review (Matthew Taylor, Good Work: The Taylor Review of Modern Working Practices (Department for Business, Energy and Industrial Strategy 2017)).

75 Abmed v BBC [2020] 1 WLUK 16; Asda Stores Ltd v Brierley [2016] EWCA Civ 566; Mrs Samantha Walker v Co-operative Group Ltd and Richard Pennycook [2018] 2403044/2016 (ET). 
high profile and highlighting significant legal cases around these issues. Together the interaction of these actors will shape the future outcomes and contested terrain for equality policy in the post-Brexit period.

Exit from the EU is likely to mean the lack of recourse to decisions made by the ECJ and removal of the scope afforded by exposure to the wider forum of the European Commission for policy development and best practice. The current indications and forecasts are that business and the economy will suffer as a result of Brexit and that this might lead us to expect the pursuit of gender equality will also suffer as it did during the financial crisis. ${ }^{76}$

We have seen how there is a long tradition of voluntarism in the UK system. Governments have tended to prefer business organisations to introduce appropriate measures themselves, so that they are not over-burdened by statutory regulation. This was evident even from the delayed implementation of the EqPA70 at the point of the UK's entry into Europe. It can also be seen in the consequences arising from the no-win nofee litigation, which led to a tightening of resources to stem this tide.

At the same time the recent introduction of compulsory gender pay audits marks a notable change in direction from this voluntarist tradition. Incorporating statutory compliance and transparency to achieve change highlights the importance of the way that the law is built on and developed in the workplace. This could be an indication supporting the work of Dobbin who argues that human resources professionals and business organisations have been largely attributed with creating the equality agenda in the USA and reducing the gender pay gap. ${ }^{77}$

Following this line of argument, we suggest that there could be two potentially unintended consequences arising from the UK withdrawal from the EU related to the impact of migration on organisations and the actions of employers, in particular in largescale international organisations.

First, we have seen, since the 2016 referendum, a fall in EU migrants coming to work in the UK. Sectors that have been particularly affected include the NHS, care homes, construction work and agriculture. As a result of labour shortages, this is likely to create wage pressure especially in low-paid jobs in these sectors. There is evidence that there has been an increase in wages, but this is still only equivalent to average wage rates in 2011, and still far below those of 2007 before the economic crisis. ${ }^{78}$ However, if labour shortages persist, and it would be reasonable to think they will, while the economy is currently expanding in terms of employment, this wage pressure is likely to increase to the potential benefit of women employed in low-waged sectors.

Second, in the USA, Dobbin argues that is has been human resources managers who have driven and created the equal opportunity and diversity agenda. ${ }^{79}$ It is plausible that

76 CBI (n 67); Nabarro and Schulz (n 67); Philip Alston, 'Statement on visit to the United Kingdom: Special Rapporteur on extreme poverty and human rights' (UN Report 2018)

<www.ohchr.org/EN/NewsEvents/Pages/DisplayNews.aspx?NewsID=23881\&LangID=E; HM>

Government, 'EU exit: long-term economic analysis' (Government Document, Cm 9742, 2018)

<https://assets.publishing.service.gov.uk/government/uploads/system/uploads/attachment_data/file/7604 84/28_November_EU_Exit_-_Long-term_economic_analysis_1_.pdf $>$.

77 Dobbin (n 4).

78 While wage growth in the UK plateaued post referendum, it is now again showing signs of growth, though still below pre-2008/2009 levels: see ONS, 'Employee earnings in the UK: 2019' (ONS 2019)

<www.ons.gov.uk/employmentandlabourmarket/peopleinwork/earningsandworkinghours/bulletins/annuals urveyofhoursandearnings/2019>.

79 Dobbin (n 4). 
for large international firms based in the UK we might expect that they are more likely to be influenced by talent management initiatives, which means recruiting highly skilled women and migrants to senior positions. These kinds of organisations are less likely to be affected by either EU or national legislation around equality if they see this strategy as an essential part of implementing best practice and recruiting highly qualified labour. It might be that the success of gender pay reporting and the space this has opened up to tackle disparities is positive. Transparency is prompting debate around how to improve measures impacting upon gender pay inequality. Organisational approaches to extend shared parental leave, or offer flexible working by default, might remain the benefits for a privileged few amongst high-status firms, or attract political support to move into a more common space.

There will perhaps be greater divergence amongst organisational sectors, whose willingness to pursue policies and their capacity to achieve change will be dependent on the different normative values that key actors hold. The extent to which organisations embrace and maintain the notion that eradicating the pay gap is good for business and not just a morally necessary goal is key. Again, here the difficulty will arise in terms of the variability between industries and organisations as good practice companies will seek to do more, while others are more complacent or, worse, actively destructive. In this way the unintended consequences of withdrawal may have less deleterious and more variegated consequences than expected. 
